\title{
Standardisation of ELISA for Rheumatoid Factor IgM Detection in Canine Serum
}

\author{
Radka Andrysíková1, Hana Kudláčkováa , Miroslav Toman ${ }^{1,2}$ \\ ${ }^{1}$ Department of Microbiology and Immunology, Faculty of Veterinary Medicine, \\ University of Veterinary and Pharmaceutical Sciences Brno, Czech Republic \\ ${ }^{2}$ Veterinary Research Institute, Brno, Czech Republic
}

Received March 11, 2008

Accepted November 12, 2008

\begin{abstract}
Rheumatoid factor (RF) is an important marker of many autoimmune diseases. Presence of RF is characteristic for rheumatoid arthritis and other inflammatory diseases of various underlying aetiologies.

The aim of our study was to introduce and standardise a convenient assay for RF-IgM detection in canine serum and to test it on a group of selected dogs. ELISA was chosen as a method of analysis due to its high specificity, selectivity and optimal quality in clinical use.

For standardised method evaluation we examined serum samples from 80 dogs classified into 4 groups as follows: I - dogs positive in the ANA test (ANA+) suffering from orthopaedic or complex diseases; II - dogs negative in the ANA test (ANA-) suffering from orthopaedic or complex diseases; III - dogs negative in the ANA test (ANA-) suffering from chronic inflammatory diseases; IV - control healthy dogs. Significant difference between mean values of RF-IgM in respective groups was detected. Dogs from groups I and II showed the highest mean values. These were significantly higher than the values in dogs from groups III and IV and the differences between the last mentioned two groups were also significant.

Our data suggest that the introduced method is suitable for use in the veterinary laboratory practice.
\end{abstract}

Rheumatoid arthritis, dog, joint, chronic inflammation, ELISA

Rheumatoid factor (RF) - a group of autoantibodies against antigenic determinants of IgG (Fc) fragment - was first described by Waaler (1940) and since the 1970s it has been observed in dogs (Bennett and Kirkham 1987). RF contributes to a more effective defence against pathogens. Accordingly, some production of RF is viewed as normal and physiologic. The RF level rises in the course of an infectious disease, with advancing age and in patients affected by autoimmune diseases. RF usually occurs as an IgM class; IgA and IgG classes are less commonly found. Hence, the IgM class (or also IgG class) is important in autoimmune disorders.

Detection of RF may be useful in diagnosing such diseases in dogs, particularly rheumatoid arthritis (RA), or in distinguishing RA from other erosive arthritides. Veterinary medicine adopted the RA diagnostic criteria from human rheumatology, which requires positivity in the serum RF test as one of those criteria.

Within 60 years, several assays have been developed for RF detection in the serum or synovial fluid (SF). Rose-Waaler test (RWT) and latex fixation test (LFT) are the oldest ones.

The turbidimetric assay, nephelometric assay and ELISA represent more recent methods. The RWT and LFT are suitable for detecting of the RF-IgM class; ELISA is able to detect RF-IgM, RF-IgA and also RF-IgG classes.

$\mathrm{RF}$ is detected mostly by indirect ELISA or by indirect sandwich ELISA. While the sensitivity and reproducibility of RWT and LFT are low, the turbidimetric and nephelometric assays are now preferred in human medicine and ELISA which is widely used in veterinary medicine, give satisfactory results. ELISA is generally viewed as the most perspective assay since only ELISA allows examination of all RF classes (IgM, IgA and IgG). Furthermore,

Address for correspondence:

Prof. MVDr. Miroslav Toman. CSc.

Veterinary Research Institute

Hudcova 70, 62100 Brno, Czech Republic
Phone: +420533332501

Fax: +420541211229

E-mail: toman@vri.cz

http://www.vfu.cz/acta-vet/actavet.htm 
this method is rapid, does not require special equipment, a small volume of sample is taken into analysis and the cost per test is relatively low.

In 1992 Nielsen described an ELISA assay applicable to RF-IgM detection in canine serum; this author also confirmed that the WHO standard of human RF-IgM was suitable as a quality control for the method (Nielsen 1992). A British team led by Bell also applied the ELISA method not only to RF-IgM detection, but also to RF-IgA detection both in serum and in SF, (Bell et al. 1993). Our study is based on their findings. RF-IgM and RFIgA were determined in a similar way in another publication (Chabanne et al. 1993).

The aim of our study was the optimisation of the ELISA method for RF-IgM detection. ELISA is a rapid, simple method, which has been used in the laboratory of the Veterinary Research Institute (VRI). The initial methodology was based on the study of Bell et al. (1993). Subsequently, we used the optimised ELISA for examination of sera from diseased and healthy dogs and we investigated whether the between-group differences in RF-IgM values were significant.

\section{Materials and Methods}

Animals

We examined a total of 80 serum samples; 60 samples were obtained from dogs with a clinically detectable disease, patients of the Clinic for Diseases of Dogs and Cats, University of Veterinary and Pharmaceutical Sciences Brno, and from veterinary practitioners. The remaining 20 samples were collected from clinically healthy donor dogs (beagles from the breeding colony of VRI), from other dogs (e.g. presented for routine vaccination) at the Clinic for Diseases of Dogs and Cats, University of Veterinary and Pharmaceutical Sciences Brno, from military working dogs of the Armed Forces of the Czech Republic; and some family-owned dogs were also included. The structure of breeds included in our study reflected the breeds most commonly found in the Czech Republic - the German Shepherd Dog, Beagle, Cocker Spaniel, Dachshund, Rottweiler, Bull Terrier, Doberman Pincher, American Staffordshire Terrier and also crossbreeds.

A serum sample from a dog with non-erosive polyarthritis served as a positive control; this control had repeatedly shown high absorbance during previous experimental testing by LFT. Mixed sera from newborn beagles were used as a negative control.

Four groups of dogs were studied. Dogs suffering from a variety of medical and surgical conditions were allocated to one of three groups according to the results of their clinical examination, radiographic and laboratory investigation (haematology, biochemistry and serology); the fourth group comprised control healthy dogs (without lameness, pain, physical or radiographic findings in the musculoskeletal system and no signs of any other disorders).

An important factor in the basic diagnostics of immune-mediated polyarthritis in dogs is the assessment of serum antinuclear antibodies (ANA) reactivity which is supposed to contribute to the exclusion of systemic lupus erythematosus (Day 1999). Hence, ANA test result served as one of the criteria for the distribution of dogs into corresponding groups.

Group I - dogs positive in the ANA test (ANA+) suffering from orthopaedic or complex diseases (diseases involving multiple organ systems) included 23 dogs with diagnosed non-erosive polyarthritis (19 cases) and erosive polyarthritis ( 1 case) or systemic lupus erythematosus ( 3 cases), with a positive result for the ANA test at the titre of $1: 100$ and greater. The age ranged between 1.5 and 11 years (the median was 4 years; the mean was 4.2 years), there were 12 males, 10 females and 1 spayed female.

Group II - dogs negative in the ANA test (ANA-) suffering from orthopaedic or complex diseases included 19 dogs with diagnosed non-erosive polyarthritis ( 2 cases), osteoarthritis (6 cases), osteochondrosis ( 1 case) or cranial cruciate ligament rupture (10 cases) with a negative ANA test. The age ranged between 2.5 and 12 years (the median was 5 years; the mean was 6 years), the sex of the animals was: 11 males, 7 females and 1 neutered male.

Group III - dogs negative in the ANA test (ANA-) suffering from chronic inflammatory diseases included 18 dogs with dermatologic disorders (deep pyoderma - 2 cases, demodicosis - 1 case, dermatitis mycofungalis - 1 case, subcutaneous abscesses - 1 case), stomatological disorders (stomatitis - 1 case, periodontitis - 5 cases, periapical granuloma - 3 cases) and gynaecological (pyometra - 3 cases, vaginitis - 1 case) disorders. The musculoskeletal system was not affected. The age ranged between 1 and 15 years (the median was 7.5 years; the mean was 7 years), there were 10 males and 8 females.

Group IV - healthy control dogs - included 20 clinically healthy individuals. The age ranged between 1 week (the beagle puppies) and 13 years (the median was 5 years; the mean was 5.9 years), there were 9 males, 10 females and 1 spayed female. 


\section{Serum samples}

Blood was obtained by aseptic venepuncture from the cephalic or jugular vein. After coagulation at room temperature for $2 \mathrm{~h}$, sera were removed from the clots by centrifugation at $600 \mathrm{~g}$ for $15 \mathrm{~min}$ at room temperature. Sera were then divided into aliquots and stored at $-20{ }^{\circ} \mathrm{C}$ until required.

Chemicals and equipment

Dog IgG (D IgG) was separated from dog sera by affinity chromatography and purified by gel chromatography at VRI. Dog serum was precipitated using a saturated solution of $\left(\mathrm{NH}_{4}\right)_{2} \mathrm{SO}_{4}$ up to a total concentration of $33 \%$ and subsequently diluted in $50 \mathrm{mM}$ phosphate buffer containing $150 \mathrm{mM} \mathrm{NaCl}, \mathrm{pH} 7.4$. Following dialysis against $50 \mathrm{mM}$ phosphate buffer, the supernatant was thickened in an ultrafiltration equipment amicon with PM 10 membrane. The affinity chromatography itself was carried out using FPLC in a column with protein G (Pharmacia) (column $2 \mathrm{ml}$ ) and purification was performed in a preparative column Superose 12 (column $270 \mathrm{ml}$ ). The purity of the selected fraction was assessed by SDS-PAGE and IELFO.

RF-IgM was detected with a goat anti-canine IgG: horseradish peroxidase conjugate (aD IgM*Px, Bethyl Laboratories Inc., Montgomery, TX, USA). RF-IgM ELISA tests were performed on the Micro-ELISA plates MaxiSorp $^{\mathrm{TM}}$ Nunc-Immuno ${ }^{\mathrm{TM}}$ Plate (Nalge Nunc International, Roskilde, Denmark, abbreviated as Nunc); alternatively for method optimisation Mikrotitracni desticka P (Gama a. s., Ceske Budejovice, Czech Republic, abbreviated as Gama) was used. The washer WeWASH 4 MK 2 (Denley Instruments LTD, Billingshurst, GB) was used. Intensity of the colour reaction (absorbance) was detected by ELISA-reader IMS READER MF (LABSYSTEMS, Helsinki, Finland) using Genesis 2.0 software (LABSYSTEMS, Helsinki, Finland). If not indicated otherwise, all chemicals were purchased from Sigma (Sigma-Aldrich, Prague, Czech Republic).

RF-IgM ELISA protocol

The RF-IgM ELISA protocol described below was chosen on the basis of testing various reaction conditions and materials and evaluating parameters and reproducibility of calibration curves.

Diluent - phosphate-buffered saline (PBS, pH 7.4), $0.05 \%$ Tween 20 and $0.5 \%$ enzymatic casein hydrolysate;

Washing solution - PBS, $\mathrm{pH} 7.4,0.05 \%$ Tween 20 ;

Detection system - substrate: hydrogen peroxide $\left(0.03 \% \mathrm{H}_{2} \mathrm{O}_{2}\right)$, chromogen $0.8 \mathrm{mM} \mathrm{TMB}$ (tetramethylbenzidine) in $0.1 \mathrm{M}$ acetate buffer, $\mathrm{pH}$ 5.6, Test Line Brno, Czech Republic

1. $100 \mu \mathrm{l}$ of antigen D IgG $(0.5 \mu \mathrm{g} / \mathrm{ml} \mathrm{PBS}), \mathrm{pH} 7.4$ was dispensed into each well of micro-ELISA plate (Nunc).

2. Antigen was incubated at $37{ }^{\circ} \mathrm{C}$ for $1 \mathrm{~h}$ (shaking in a thermostat) and then at $4{ }^{\circ} \mathrm{C}$ in a refrigerator overnight.

3. Plates were washed $(\times 3)$ with washing solution and then $100 \mu 1$ of serum sample or control sample was added in duplicates into the wells (sera and control samples were pre-diluted $1: 10$ with the diluent).

4. The serum samples were diluted with the diluent: $1: 100,1: 1000$ and $1: 10000$ and both the controls were diluted threefold: $1: 30,1: 100,1: 300,1: 1000,1: 3000,1: 10000$ and $1: 30000$.

5. Samples and controls were incubated at $37^{\circ} \mathrm{C}$ for $1 \mathrm{~h}$ (shaking in a thermostat).

6. Plates were washed $\times 3$ with washing solution.

7. $100 \mu 1$ of conjugate aD IgM*Px diluted $\times 20000$ with the diluents was dispensed into each well.

8. Wells with the conjugate were incubated at $37^{\circ} \mathrm{C}$ for $1 \mathrm{~h}$ (shaking in the thermostat) and then for $1 \mathrm{~h}$ at $4{ }^{\circ} \mathrm{C}$ in the refrigerator.

9. Plates were washed $\times 3$ with washing solution.

10. Subsequently, the substrate $\left(\mathrm{H}_{2} \mathrm{O}_{2}\right)$ and chromogen (TMB) mixed $1: 1$ were added at a volume of $100 \mu \mathrm{l}$ to each well.

11. Plates were incubated at room temperature for $15 \mathrm{~min}$.

12. The absorbance (colour reaction) was determined at $450 \mathrm{~nm}$ immediately after the addition of $50 \mu \mathrm{l}$ of $2 \mathrm{M} \mathrm{H}_{2} \mathrm{SO}_{4}$ (stop solution) to each well.

13. The absorbance values of both controls were used as a base for calibration curve construction.

14. RF-IgM value of each sample was expressed as a percentage of the absorbance relative to the positive control absorbance at an appropriate dilution. The standard serum could also be used for the calibration.

Optimisation of RF-IgM ELISA

During optimisation of the method, we tested two microtitration plates Nunc and Gama, buffers with $\mathrm{pH}$ ranging from 8.6 to 9.6 , sample incubation times from overnight to $1 \mathrm{~h}$, different incubation temperatures from $4{ }^{\circ} \mathrm{C}$ to $37^{\circ} \mathrm{C}$, antigen concentration $25 \mu \mathrm{g} / \mathrm{ml}, 10 \mu \mathrm{g} / \mathrm{ml}$ and $0.5 \mu \mathrm{g} / \mathrm{ml}$ and the effect of blocking the antibody presence/absence. The character of the calibration curve for different concentrations of our positive control sample was the most important criterion for evaluating the method modifications.

Statistical analyses

Statistical and graphic software STAT Plus, VRI Brno (Matoušková et al. 1992) was used for statistical evaluation of data. After elimination of the deviating values, normality of basic statistical distribution was investigated using a frequency diagram. If needed, the Box-Cox's transformation was used. Unpaired $t$-test for equal and unequal variances was performed to test for significant differences between RF-IgM values in different groups. Data in groups were compared to ascertain whether there were significant differences. Finally, multifactor analysis of variance was performed to detect variability. The part of variability caused by measurement errors on three consecutive days was determined. 


\section{Results}

Reproducibility of RF-IgM ELISA

We analysed data acquired by independent repeated measurements of all 80 canine sera including the positive and negative controls on the Nunc plates on three consecutive days.

The multifactor analysis of variance showed that the part of the data variability which was caused by differences between measurements on three consecutive days, i.e. the degree of reproducibility, was higher at the $1: 1000$ dilution (variance estimation $\sigma^{2}=59.2$ ) than at 1 : 100 (variance estimation $\sigma^{2}=17.8$ ). The $1: 100$ dilution was evidently associated with a lower measurement error. The measurements were also associated with a lower error at both analysed dilutions if Nunc plates were used instead of Gama plates $\left(\sigma^{2}=210.2\right.$ at the $1: 100$ dilution and $\sigma^{2}=88.9$ at the $1: 1000$ dilution, respectively).

Hence, the most reproducible results were obtained at the $1: 100$ dilution when using Nunc plates.

Standard ELISA was monitored using intra- and interassay. Two sera with low absorbance and two sera with high absorbance in 16 replications on one plate were used in the intraassay. Interassay was carried out in 6 replications with four sera (2 with low and 2 with high absorbance), each in triplicates.

Serum dilution as a factor in canine RF-IgM level assessment

We assessed the RF-IgM values obtained at three dilutions of sera (1:100, $1: 1000,1: 10000)$ in four groups of dogs according to the above described protocol. There were marked differences between the values of positive and negative controls at $1: 100$ and $1: 1000$ dilutions (the ratio of values was $6.9: 1$ at the $1: 100$ dilution and $4.1: 1$ at the $1: 1000$ dilution). The course of the standard curve was of a sigmoid shape at these two dilutions. Differences between the values of positive and negative controls were indistinguishable $(1.7: 1)$ at the $1: 10000$ dilution and accordingly, this dilution was not suitable for measurements of the examined samples. Thus we did not perform a detailed statistical analysis for this dilution (1: 10 000).

Complete comparisons of results obtained with all the dilutions are presented in Fig. 1. Dilutions of $1: 100$ and $1: 1000$ proved to be satisfactory. The coefficient of correlation for the whole range of values at the dilution of $1: 100$ measured in intraassay was $14.6 \%$, in interassay $18.5 \%$.

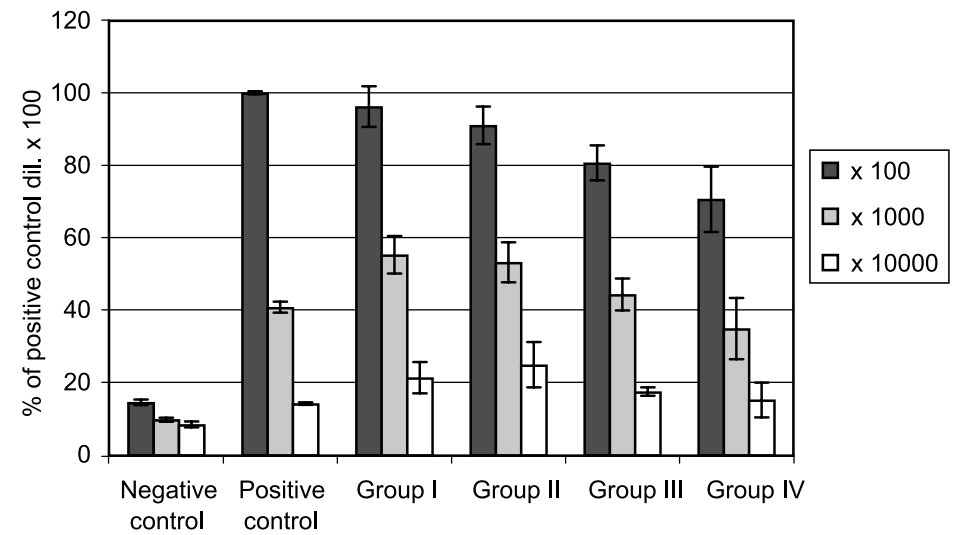

Fig. 1. Comparison of RF-IgM average values obtained with all the sera dilutions $(1: 100,1: 1000,1: 10000)$

Group I - dogs suffering from orthopaedic or complex diseases ANA +

Group II - dogs suffering from orthopaedic or complex diseases ANA -

Group III - dogs suffering from chronic inflammatory diseases ANA -

Group IV - healthy control dogs 
Table 1. RF-IgM value differences between groups of dogs at serum dilution 1:100

\begin{tabular}{|c|c|c|c|c|c|}
\hline Group & Mean & Standard deviation & Variation coefficient & Value range & Median \\
\hline I & 96.4 & 19.6 & $20.3 \%$ & $67.1-123.0$ & 96.6 \\
\hline II & 91.1 & 23.4 & $25.7 \%$ & $43.4-148.9$ & 90.1 \\
\hline III & 80.6 & 22.5 & $27.8 \%$ & $34.0-110.0$ & 84.3 \\
\hline IV & 71.4 & 26.5 & $37.2 \%$ & $16.7-126.4$ & 70.7 \\
\hline
\end{tabular}

Group I - dogs suffering from orthopaedic or complex diseases ANA+

Group II - dogs suffering from orthopaedic or complex diseases ANA-

Group III - dogs suffering from chronic inflammatory diseases ANA-

Group IV - healthy control dogs

\section{RF-IgM value differences between groups of dogs}

Dilution of $1: 100$

RF-IgM results obtained at serum dilution of $1: 100$ are presented in Table 1. After the calculation of percentages relative to positive control absorbance, the lowest mean value was detected in group IV (healthy control), i.e. 71.4. This value was significantly lower ( $p<$ 0.01 ) than the value (80.6) detected in group III (dogs suffering from chronic inflammatory diseases ANA-) the value (91.1) in group II (dogs suffering from orthopaedic or complex diseases ANA-) and the value (96.4) in group I (dogs suffering from orthopaedic or complex diseases ANA+). The second lowest value was noted in group III, i.e. 80.6. This value was significantly lower $(p<0.01)$ than in group II (91.1) and group I (96.4).

Table 2. RF-IgM value differences between groups of dogs at serum dilution 1:1000

\begin{tabular}{|c|c|c|c|c|c|}
\hline Group & Mean & Standard deviation & Variation coefficient & Value range & Median \\
\hline I & 55.6 & 22.4 & $40.4 \%$ & $32.7-84.6$ & 49.3 \\
\hline II & 52.1 & 27.3 & $52.4 \%$ & $18.5-141.2$ & 45.0 \\
\hline III & 44.5 & 19.0 & $42.6 \%$ & $12.4-78.3$ & 44.1 \\
\hline IV & 35.3 & 23.2 & $65.7 \%$ & $10.7-105.5$ & 28.7 \\
\hline
\end{tabular}

Group I - dogs suffering from orthopaedic or complex diseases ANA+

Group II - dogs suffering from orthopaedic or complex diseases ANA-

Group III - dogs suffering from chronic inflammatory diseases ANA-

Group IV - healthy control dogs

\section{Dilution of $1: 1000$}

RF-IgM results obtained at serum dilution $1: 1000$ are presented in Table 2. The lowest mean value was again detected in group IV (healthy control), i.e. 35.3. This value was significantly lower $(p<0.01)$ than the value (44.5) detected in group III (dogs suffering from chronic inflammatory diseases ANA-), the value (52.1) in group II (dogs suffering from orthopaedic or complex diseases ANA-) and the value (55.6) in group I (dogs suffering from orthopaedic or complex diseases ANA + ). The second lowest value was again noted in group III, i.e. 44.5. This value was significantly lower $(p<0.01)$ than in group I (55.6).

Individual RF-IgM values

Even though the investigation of the RF-IgM values in individual animals was not the aim of our study, we obtained some noteworthy results that are presented here. However, due to the fact that some diagnoses may not have been accurate, it is difficult to make definitive conclusions.

A dog with suspected RA showed high RF-IgM values (103.4 at the $1: 100$ dilution, mean value was 96.4 at this dilution) with concurrent positivity in the ANA test. The dogs with polyarthritis (the type was not identified) had high RF-IgM values in about $75 \%$ of cases (values ranged between 94.5 and 121.3 at the $1: 100$ dilution) but about one half 
of them were also positive in the ANA test. Three dogs with a suspected diagnosis of systemic lupus erythematosus had high RF-IgM values (between 83.5 and 100.1 at the $1: 100$ dilution) and a positive ANA test. In the group of animals affected by chronic inflammatory diseases, high RF-IgM values were detected in bitches with spontaneous pyometra (99.1 at the $1: 100$ dilution), with vaginitis (99.3 at the $1: 100$ dilution), in dogs with periodontitis (96.4 at the $1: 100$ dilution), stomatitis (87.7 at the $1: 100$ dilution), repeated respiratory and intestinal tract infections (104.9 at the $1: 100$ dilution) and in a dog with pyoderma (97.9 at the $1: 100$ dilution); contrariwise RF-IgM was low in another case of pyoderma (only 51.1 at the same dilution).

\section{Discussion}

At present, RF is not tested routinely in the Czech veterinary laboratories, although the test is commonly available in other countries (Barta 1993; Bell et al. 1993; Chabanne et al. 1993; Day 1999). Methods based on the agglutination of sensitised particles (RWT and LFT) or ELISA are used for RF detection in serum and SF. ELISA is the most sensitive and specific method (Visser et al. 1996; Wener 2002). It is a rapid test, easy automation is possible, many samples can be examined simultaneously; quantification of the results and detection of different RF classes by using proper detecting systems is possible and the use of human standard serum is convenient.

The ELISA assay allows detection of various RF classes. However, we preferred detection of RF-IgM because it is present in the highest levels in serum and is generally considered as playing an important role in the pathogenesis of RA.

The initial methodology was based on the study of Bell et al. (1993) but our method was modified markedly during optimisation. Although there is a dissimilar distribution of diagnoses in our study and there are no standardized control samples available, our results are in agreement with previously published data (Bell et al. 1993; Chabanne et al. 1993).

The final ELISA modification provided an acceptable calibration curve; the curve had a sigmoid shape, sample absorbances approximated to the background values when diluted at $1: 100$ and there was a significant difference between the values of positive vs. negative control.

The dilution of $1: 100$ was associated with a smaller error than the $1: 1000$ dilution according to the statistical analysis. In practical application of this method, it will be possible to analyse the absorbance values at a dilution higher than $1: 100$, which is associated with a low measurement error, and lower than $1: 1000$, where the value of negative control approximates the background value.

We detected the highest mean values in group I (dogs suffering from orthopaedic or complex diseases - ANA+) and group II (dogs suffering from orthopaedic or complex diseases - ANA-) at both dilutions used. These mean values were significantly higher than in group III (dogs suffering from chronic inflammatory diseases - ANA-). The mean values in group IV (healthy control) were the lowest at both dilutions.

An interesting finding was that a dog with suspected RA showed high RF-IgM values (103.4 at the $1: 100$ dilution, the mean value was 96.4 at this dilution) with a concurrent positive ANA titre. This fact need not contradict the suspected diagnosis of RA since some cases may be positive for both RF and ANA (Day 1999).

We can conclude that RF-IgM values rise significantly in individuals with a chronic inflammatory disease in contrast to control healthy dogs. If the disorders (degenerative or inflammatory) were localised in the musculoskeletal system, e.g. in joints, the RF-IgM values were higher than the values of patients with an inflammation localised in other organ systems. Of course, individual differences exist - for example high RF-IgM values were detected in bitches with spontaneous pyometra (99.1 at the $1: 100$ dilution), which was 
confirmed by another study (Chabanne et al. 1993); these limit the applicability of the method to individual diagnosis.

Thoren-Tolling found significantly lower $(p<0.001)$ absorbance values in the control group of normal dogs compared to a rheumatic disease group when measuring RF-IgM by ELISA (Thoren-Tolling 1990). Bell detected significantly higher RF-IgM values $(p<0.001)$ in the dogs with systemic lupus erythematosus in comparison with the dogs suffering from RA and normal dogs. However, the dogs with RA had higher levels of RFIgM than normal control dogs and dogs with osteoarthritis. Their conclusions concerning serum RF-IgA also showed significantly elevated levels in the dogs with RA in contrast to the control group $(p<0.05)$ and its increase in dogs with systemic lupus erythematosus was even more significant $(p<0.001)$ than in either the control or RA groups (Bell et al. 1993). In a previous study using radioimunoassay, the same team of authors found that the dogs suffering from RA had an elevated RF-IgM titre in both serum and SF compared to healthy dogs; the elevation was marked in serum. Some increase was observed in dogs suffering from other arthropathies (septic arthritis, osteoarthritis and osteoarthritis secondary to cranial cruciate ligament rupture groups) (Carter et al. 1989).

There is correlation of the RF titre with the age of beagle puppies classified as normal (group IV). The mean value of 16.7 at the dilution of $1: 100$ at the age of 1 week was found, which corresponded to the negative control value. Values of 46.6 and 74.2 at the age of 5.5 weeks and 4.5 months, respectively (both at the $1: 100$ dilution) were recorded. It remains unclear how the serum level is influenced by colostrum intake in the youngest puppies. It is reported in calves that besides the increasing titres of RF-IgM and RF-IgG with age, RFIgM titre was significantly higher in calves that ingested colostrum $(p<0.001)$ (Graham et al. 1998). There is no comparable information for carnivores.

Conclusions from published data would be more consistent if a standard method existed so that all laboratories used the same source of antigen, the same standard serum for calibration and prepared the samples in the same way.

Another factor that can affect the detection of RF is the "hidden" RF (RF masked by an immune complex), which cannot then be detected. The origin of the examined samples (serum vs. SF) is also relevant since RF can sometimes be detected in SF but serum examination is negative (Rovenský et al. 1998).

Based on the analysis of data acquired by examination of 80 serum samples from control healthy dogs and from dogs with various disorders we found that dogs suffering from orthopaedic or complex diseases and positive for ANA had the highest mean RF-IgM values at both analysed dilutions (1:100 and $1: 1000)$, followed by dogs suffering from orthopaedic or complex diseases and negative for ANA while control healthy dogs had the lowest mean values. Considerable individual differences were found within the groups.

It follows that RF can be used as one of the criteria to distinguish between an immunemediated and other types of arthritis but it is not a specific indicator or individual diagnosis of RA and other canine diseases. RF determination gives information about a disease in the patient but the assessment should be considered together with clinical signs and other laboratory findings before making a final diagnosis.

\section{Standardizace ELISA pro detekci reumatoidního faktoru IgM v krevním séru psů}

Revmatoidní faktor (RF) je významným markerem řady autoimunitních onemocnění. Jeho přítomnost je charakteristická pro revmatoidní artritidu a další zánětlivá onemocnění nejrůznější etiologie.

Cílem naší práce bylo zavést a standardizovat vhodnou metodu pro stanovení RF-IgM v psím séru a tuto metodu otestovat na souboru vybraných psů. Zvolili jsme metodu ELISA 
pro její vysokou specifitu, selektivitu a optimální kvalitu s ohledem na využití v klinické praxi.

Po úspěšné standardizaci jsme touto metodu vyšetřili soubor sér získný od 80 psů rozdělených do 4 skupin podle následujícího schématu: I) psi s pozitivním výsledkem ANA testu (ANA+) trpící ortopedickým nebo komplexním onemocněním; II) psi s negativním výsledkem ANA testu (ANA-) trpící ortopedickým nebo komplexním onemocněním; III) psi s negativním výsledkem ANA testu (ANA-) s chronickým zánětlivým onemocněním; IV) zdraví kontolní psi. Uvedené skupiny vykázaly statisticky signifikantní rozdíly mezi průměrnými hodnotami RF-IgM. Nejvyšších průměrných hodnot RF-IgM dosáhli psi ze skupin I) a II) a tyto hodnoty byly signifikantně vyšší než hodnoty III) a IV) skupiny, avšak i rozdíly mezi skupinami III) a IV) byly statisticky významné.

Výsledky naší studie potvrzují, že tato metoda je vhodná pro využití ve veterinární laboratorní praxi.

\section{Acknowledgement}

The work was supported with the grant of Ministry of Agriculture of the Czech Republic No. 0002716201.

\section{References}

Barta O 1993: Tests for detection of rheumatoid factors. In: Barta O (Ed.): Veterinary clinical immunology laboratory. Bar-Laboratory, Inc., $350 \mathrm{p}$.

Bell SC, Carter SD, May C, Bennett D 1993: IgA and IgM rheumatoid factors in canine rheumatoid arthritis. J Small Anim Pract 34: 259-264

Bennett D, Kirkham D 1987: The laboratory identification of serum rheumatoid factor in the dog. J Comp Pathol 97: $541-50$

Carter SD, Bell SC, Bari AS, Bennett D 1989: Immune complexes and rheumatoid factors in canine arthritides. Ann Rheum Dis 48: 986-91

Chabanne L, Fournel C, Faure JR, Veysseyre CM, Rigal D, Bringuier JP, Monier JC 1993: IgM and IgA rheumatoid factors in canine polyarthritis. Vet Immunol Immunopathol 39: 365-79

Day MJ 1999: Clinical immunology of the dog and cat. $1^{\text {st }}$ ed. Iowa State University Press/Manson Publishing Ltd., London, 288 p.

Graham DA, Mawhinney KA, Adair BM, Merza M 1998: Testing of bovine sera by ELISA for IgG, IgM and IgA rheumatoid factors. Vet Immunol Immunopathol 61: 239-250

Matoušková O, Chalupa J, Cigler M, Hruška K 1992: STAT PLUS - User's manual. VÚVeL, Brno, 168 p.

Nielsen OL 1992: Detection of IgM rheumatoid factor in canine serum using a standardized enzyme-linked immunosorbent assay. Vet Immunol Immunopathol 34: 139-147

Rovenský J, Cebecauer L, Lukáš J 1998: Klinický význam autoprotilátok pri systémových chorobách spojivového tkaniva. In: Rovenský J et al. (Eds.): Reumatológia v teórii a praxi V. Osveta, Martin, pp. 235-254

Thoren-Tolling K 1990: A comparative study of different methods for measurement of rheumatoid factor in dog serum. Zentralbl Veterinarmed A 37: 430-438

Visser H, Gelinck LB, Kampfraath AH, Breedveld FC, Hazes JM 1996: Diagnostic and prognostic characteristics of the enzyme linked immunosorbent rheumatoid factor assays in rheumatoid arthritis. Ann Rheum Dis 55: 157-61

Waaler E 1940: On the occurrence of a factor in human serum activating the specific agglutination of sheep blood corpuscles. Acta Pathol Microbiol Scand 17: 172-188

Wener MH 2002: Rheumatoid Factors. In: Rose NR, Hamilton RG, Detrick B (Eds.): Manual of clinical laboratory immunology. $6^{\text {th }}$ ed. American Society Microbiology Press, Washington, D.C., pp. 961-972. 